\title{
HISTÓRIA ŠKOLSTVA NA SLOVENSKU SO ZRETEL'OM NA SOCIÁLNU PRÁCU
}

\begin{abstract}
Resume
Autor sa zameral na slovenské dejiny pedagogiky od najstarších čias, školskú sústavu v rámci školského systému Ratio educationis, kde dopodrobna opisujeme ludové a latinské školy a štúdium na akadémiách a samotných lýceách $\mathrm{v}$ jednotlivých podkapitolách
\end{abstract}

Klúčové slová: Dejiny pedagogiky. Škola a výchova. Ratio educationis. Ludové školy. Latinské školy.

\section{Náčrt problému}

Z najstarších období slovenských národných dejín sa nám nezachovali písomné správny o výchove a spôsobe vzdelávania našich predkov. Krestanstvo tvorilo ideológiu feudálnej spoločnosti a vzdelanost́ bola do obdobia renesancie, okrem malých výnimiek, majetkom kléru. Do osvietenstva školstvo a čiastočnej aj obsah vzdelávania podliehali cirkvi. Široké masy dostávali v najstarších obdobiach isté vzdelanie iba v rodine a pri pracovných príležitostiach, v procese práce, prípadne si osvojili základné náboženské články pri bohoslužbách. (Mátej, J., 1986. s. 51).

Súveká slovienska vzdelanost' sa formovala na rozhraní dvoch v podstate nadnárodných kultúr - latinskej a gréckej (byzantskej) kultúry. Jazyk domáceho obyvatel'stva sa formoval v praslovanskom jazykovom areáli v priebehu 7. - 10. storočia so silnými integračnými tendenciami, ktoré ovplyvnil najmä vývoj v 9. storočí. Slovienčina* bola aj jazykom vel'komoravskej elity, ale bola vel'mi blízka jazyku

* Slovienčina, staroslovienčina, stará cirkevná slovančina, staroslovenčina, stará slovenčina sú všetko názvy pre najstarší slovanský spisovný jazyk. Spisovná norma vznikla na základe ma- 
včasnostredovekých domácich dialektov obyvatel'ov Vel'kej Moravy. (Čaplovič, D. a kol., 2000. s. 88)

\section{História prvých škôl}

Prvou bola pravdepodobne škola, v ktorej Cyril a Metod učili svojich žiakov po príchode do Vel'komoravskej ríše. Priame správy o nej sa však nezachovali. Prvú kláštornú školu založili benediktíni koncom 10. storočia pod Zoborom, o ktorej je však zmienka v liste až z r. 1111. Podobné školy mali aj kláštory v Beňadiku nad Hronom a v Bzovíku. Najstaršie farské školy pochádzajú tiež z 12. a 13. storočia. Jestvovali najmä pri väčších mestských farách. O farských školách sa však zachovalo málo správ, lebo Tatári, Turci a iné vojská vypálili takmer všetky kapitulárne, kláštorné i mestské archívy. (Srogoň, T., 1981. s. 72)

$\mathrm{V}$ priebehu 13. storočia došlo aj k zvýšeniu vzdelanostnej úrovne spoločnosti. Najstaršie školy v tomto období nachádzame pri dôležitých cirkevných inštitúciách - kapitulách, ktoré boli v Bratislave, Nitre a Spišskom Podhradí. Školy existovali aj pri významnejších kláštoroch (Zobor, Hronský Beňadik, Jasov) a v druhej polovici 13. storočia už aj v najvýznamnejších stredovekých mestách (Trnava, Banská Štiavnica, Košice). (Čaplovič, D. a kol., 2000. s. 114)

Štúdium na kapitulských školách nepresahovalo v priebehu 13. a 14. storočia trivium. Okrem čítania, písania a spevu sa vyučovala latinská gramatika, logika a rétorika. Vo vyučovaní gramatiky sa používala Donatova učebnica „Ars minor“. Učitelia alebo pokročilejší pedagógovia používali aj Priscianovu „Institutio de arte grammatica“. Na kapitulských školách sa vzdelával nielen kňazský dorast, ale aj laici. Ani kňazský dorast v 14. a 15. storočí sa nevzdelával v Uhorsku výlučne na kapitulských alebo kláštorných školách, lež i na školách pri väčších farnostiach. (Mátej, J., 1986. s. 51- 52)

Humanizmus na území Slovenska sa tradoval od druhej polovice 15. storočia. $\mathrm{V}$ nasledujúcom storočí humanistické hnutie postupne prechádza do reformácie. Centrami humanizmu stávajú sa predovšetkým mestá. Hospodárska prosperita viacerých slovenských miest v 14. a 15. storočí a priaznivé kultúrne podmienky vábili na Slovensko humanisticky vzdelaných ludí zo zahraničia. Dobré podmienky pre rozvoj humanizmu mali mestá na východnom Slovensku, ktoré zaznamenali hos-

cedónskeho nárečia (kultivovaná macedónčina) používaného v okolí Solúna v 9. storočí. S určitými zmenami sa používa dodnes, nie už však ako živý jazyk, ale ako bohoslužobný jazyk katolíckej cirkvi byzantského obradu (tzv. gréckokatolíckej) a pravoslávnych cirkví. http:// sk.wikipedia.org/wiki/Staroslovien\%C4\%8Dina, 06. 05. 2009, 21:27 
podársku konjunktúru vd’aka obchodu s Pol’skom (Levoča, Kežmarok, Bardejov, Košice, Prešov), zo stredoslovenských boli to banské mestá (B. Štiavnica, B. Bystrica, Kremnica), na západnom Slovensku predovšetkým Bratislava, ktorá vzhladom na blízkost́ Viedne stala sa nielen na slovenskom území, ale i v celom Uhorsku strediskom politického a kultúrneho hnutia. (Srogoň, T., 1981. s. 65)

V druhej polovici 15. storočia dozreli aj v Uhorsku podmienky na založenie vlastnej univerzity. Z podnetu krála Mateja Korvína roku 1465 vydal pápež Pavol II. bulu povolujúcu zriadit’ v Bratislave univerzitu. Podl'a humanistického gréckeho názvu mesta (Istropolis) sa začala volat Univerzita Istropolitana. Jej kancelárom sa stal ostrihomský arcibiskup humanista Ján Vitéz zo Sredny. Vyučovat sa na novej univerzite začalo až na jeseň 1467 . Vicekancelárom univerzity sa stal bratislavský prepošt Juraj Schomberg, ktorý sa po smrti Jána Vitéza (1472) sám začal starat́ o chod celej univerzity a jej materiálne zabezpečenie. Po jeho smrti roku 1486 univerzita postupne zanikla, lebo nemala primerané materiálne zabezpečenie na svoju d'alšiu činnost́. Nezištnú pomoc univerzite v jej začiatkoch poskytli profesori z blízkej Viedne. V Bratislave pôsobili mnohí významní stredovekí učenci ako boli Ján Müller z Köningsbergu (Regiomontanus) a jeho žiak Martin Bylica z Olkusza, dalej právnik Ján Gattus a teológovia Mikuláš Gruber a spišský nemec Vavrinec Koch z Krompách. (Čaplovič, D., 2000. s. 130)

Smrtou krála Mateja Korvína (1490), mocného uhorského magnáta a feudála, rozkladala sa triednou politikou uhorských magnátov absolutistická jednota uhorského štátu, hoci vykazovala na tú dobu značný politický, vojenský a kultúrny rozmach. Snažil sa udržat vo svojom štáte všetkými prostriedkami jednoliaty, pevný, až mocenský katolícky ráz. Upevňoval ho nielen účinnou podporou starších a zakladaním nových reholných domov a kláštorov, ale katolícky charakter krajiny mala umocňovat aj ním založená v Bratislave v roku 1465 Academia Istropolitana - prvá univerzita na pôde slovenského územia. (Ružička, V., 1974. s. 21)

Koncom 15. storočia sa v Uhorsku okrem latinských škôl vznikali v mestách aj tzv. pisárske školy (Briefschulen, Schreibschulen). Tieto školy vznikali skôr pre praktické potreby meštanov, žiaci sa v nich učili čítat, písat a trocha aj počítat. Náplňou týchto škôl bolo najmä, aby sa žiaci naučili zostavovat rozličné písomnosti, týkajúce sa remesiel a obchodu. Boli to školy súkromné a mohli sa zriad'ovat so súhlasom mestskej rady. (Mátej, J. a kol., 1976. s. 57)

V 16. storočí sa pod vplyvom reformácie prejavoval kvantitatívny rast škôl nielen v mestách, ale aj na dedinách. Tento trend sa udržiaval ešte v nasledujúcom storočí. Vel'ký rozvoj zaznamenali partikulárne školy, objavovali sa pokusy o osamostatnenie školy spod právomoci cirkvi. Osobitným druhom boli patronátne školy. Aj napriek týmto snahám mestské školy zostali v područí jednotlivých cirkví. Organizácia škôl, obsah vzdelania, výchovy a disciplínu tohto obdobia poznáme 
zo školských poriadkov. Protestantské školy preberali spočiatku organizáciu podla nemeckých školských poriadkov (Saský, Wittenberský, Vratislavský, Šturmov školský poriadok), neskôr sa upúštalo od mechanického preberania cudzích vzorov, pri ich tvorbe sa berie zretel' na vlastné tradície školy a miestne podmienky sídla školy, často aj osobnost́ rektora poznačila charakter školských poriadkov. Tieto okolnosti spôsobovali, že organizácia protestantského školstva je rôznorodá. (Srogoň, T., 1981. s. 72)

Zo 16. storočia máme už správy o pisárskych alebo nemeckých školách v Banskej Bystrici, Banskej Štiavnici, Kežmarku a Kremnici. Pisárske školy musíme odlišovat' od pokútnych škôl (scholae cubiculariae, Minckelschulen, clancariae). $\mathrm{Na}$ existenciu takýchto škôl poukazuje i zákaz vyučovat mimo školy v Bratislave (r. 1551). Ucelenejší a presnejší obraz o organizácii škôl, o rozsahu vzdelávania, o vyučovacích metódach, disciplíne a učebných pomôckach si môžeme utvorit až $\mathrm{v}$ druhej polovici 16. storočia. Z tohto obdobia sa nám zachovali študijné a disciplinárne poriadky z niektorých latinských škôl na Slovensku. (Mátej, J. a kol., 1976. s. 59)

Slovenský humanizmus v 16. storočí usmerňoval svojím vplyvom Erazmus Rotterdamský. Ním skyprený nový pokrokový smer prúdil z uhorského král'ovského dvora od Bratislavy až po severné a východné pomedzie krajiny. Slovenské mestá boli v porovnaní s mestami talianskymi a západoeurópskymi ovel'a menšie aj chudobnejšie, preto u nás reprezentovala nový smer ideológie okrem aristokracie iba slabá vrstva intelektuálov. Slovenský humanizmus sa staval od samého začiatku nielen na oživení antickej kultúry, ale súčasne budoval aj novodobý svetonáhlad so sklonom k racionalizmu ${ }^{*}$, individualizmu ${ }^{* *}$, kriticizmu ${ }^{* * *}$ a naturalizmu ${ }^{* * *}$. (Ružička, V., 1974. s. 20)

Slovensko v 16. a 17. storočí malo významné postavenie. Vtedy územie Slovenska tvorilo jadro Uhorska po obsadení jeho južnej a strednej časti Turkami. Hlavným sídlom sa stala Bratislava. Okrem základného a stredného školstva vzrástol záujem aj o vysoké školy. Roku 1635 vznikla univerzita v Trnave. Univerzita vznikla

\footnotetext{
* smer pokladajúci rozum za jediný alebo rozhodujúci zdroj poznania, presvedčenie o neobmedzených schopnostiach ludského rozumu; rozumový (racionálny) postoj;

** nezávislost́ jedinca od skupinových a spoločenských noriem či štandardov; resp. spôsob myslenia a konania, prípadne teoretické poňatie vychádzajúce zo záujmu a práv jedinca poňatého ako nezastupitel'ná osobnost', ktorú musí dané spoločenské usporiadanie rešpektovat;

*** sklon ku kritizovaniu, kritický postoj, kritickost'; filoz. Kantov prevratný názor, že treba začínat od kritiky našich poznávacích možností (najmä jeho kritika čistého rozumu);

**** filoz.- názor popierajúci nadprirodzené a pokladajúci prírodu za jediný a univerzálny princíp výkladu všetkých javov, resp. v etickom zmysle požiadavka žit v hode s prírodou, odvodzovat mravné pojmy z prirodzených záujmov, potrieb, pudov a pod.; sociol. výklad spoločenských a dejinných fenoménov z faktorov prírodných, najmä biologických;
} 
ako cirkevná (katolícka) vysoká škola. Bola v tom čase v Uhorsku jedinou vysokoškolskou inštitúciou. Pri vzniku mala trnavská univerzita dve fakulty - filozofickú a teologickú, od roku 1667 právnickú a ako posledná sa otvorila lekárska*. Na filozofickej fakulte sa prednášala aj matematika, z prírodných vied fyzika, botanika a chémia. Činnost́ univerzity v Trnave sa ukončila v r. 1777, kedy sa premiestnila do Budína a odtial'v roku 1834 do Pešti. (Srogoň, T., 1981. s. 75)

Druhým vysokoškolským centrom na Slovensku boli Košice. V roku 1657 tu vznikla akadémia s charakterom vysokej školy, potvrdená cisárom Leopoldom I. roku 1660. Košická univerzita mala tri fakulty - filozofickú, teologickú a právnickú. Aj tu sa na filozofickej fakulte vyučovala matematika a fyzika. Po zrušení jezuitského rádu v roku 1773 sa teologická fakulta vyčlenila zo zväzku univerzity. (Srogoň, T., 1981. s. 75)V 16. storočí čerpali naši vzdelanci idey humanizmu a renesancie z pôvodného prameňa na talianskych univerzitách. Ale ked' Turci ohrozili bezpečnost́ ciest na európsky juh, študenti z uhorskej kotliny sa uchylovali za svojím vzdelaním spočiatku do Krakova a Viedne. Reformácia odpútala protestantské študentstvo od katolíckej Viedne a Pol'ska a primkla ho ku kolíske reformácie - Wittenbergu a k Nemecku všeobecne. Humanizmus na Slovensku stráca preto v 16. - 18. storočí pôvodný teoretický, aristokratický aj estetizujúci* nádych a na-

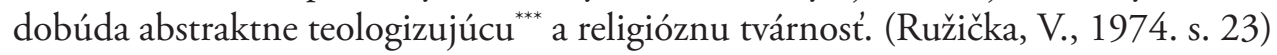

V 17. storočí sa v Uhorsku stretneme s úsilím o jednotnú úpravu vyučovacieho poriadku, a to na poradách siedmich banských miest a na generálnej synode ${ }^{* * * *} \mathrm{v}$ Pezinku. 4. marca 1658 zasadalo kňazstvo banských miest v Kremnici a navrhlo, aby sa vypracoval jednotný učebný poriadok pre latinské školy siedmich banských miest. Tento návrh si osvojili aj magistráty a nariadili, aby sa postúpili seniorovi školské zákony a učebne poriadky na preskúmanie. (Mátej, J. a kol., 1976. s. 151)

Politické udalosti v posledných desatročiach 17. storočia zasiahli protestantské školstvo. Z vel'kého počtu evanjelických gymnázií, ktoré boli založené pred rokom 1640, zostalo na Slovensku začiatkom 18. storočia len desat́. (Čaplovič, D., 2000. s. 155)

Návrh jednotného študijného poriadku sa predložil synode siedmich banských miest. Táto sa zišla v Kremnici 23. mája 1659, kde sa však neustálil nový jednotný študijný poriadok, len sa schválili pre školy učebnice (Rheniova gramatika latinského jazyka, Velleiova gramatika gréckeho jazyka, Donoverova

\footnotetext{
* táto fakulta sa zriadila až v roku 1770, kedy sa uskutočnila reforma trnavskej univerzity. Touto reformou univerzita dostala sa pod vplyv viedenského dvora (poznámka autora);

** hodnotit len z hladiska krásy a umenia, obyčajne jednostranne;

*** robit niečo teologickým, resp. zaoberat' sa teológiou;

**** cirkevný snem; v katolíckej cirkvi (od 2. Vatikánskeho koncilu) všeobecný koncil, neskôr regionálny snem;
} 
učebnica logiky, Dietericova rétoriky a teológie a Stalariova učebnica metafyziky) a v závere sa Janua linguarum odporučila učitel'om na objasňovanie učiva žiakom. V roku 1667 sa v Pezinku na generálnej synode uzniesli aby sa podla možnosti zachovávala jednotnost́ vo vyučovaní a odporučili učebnice (Rheniovu gramatiku, Scharfiovu logiku a Wossiovu rétoriku). Ustanovilo sa i to, aby sa bez vysvedčenia neprijímali alebo neprepúštali žiaci zo školy. Na evanjelických školách sa zaviedlo jednotné vyučovanie až v druhej polovici 19. storočia. (Mátej, J. a kol., 1976. s. 148)

Nepriaznivý hospodársky a politický vývin na Slovensku v 17. storočí sa výrazne prejavil aj v oblasti kultúry. Nastalo úzke spojenie náboženstva a kultúry. Cirkev inštitucionálne a organizačne kontrolovala školstvo, väčšiu čast' vedeckého života, literatúry a významne vplývala na výtvarné umenie. Politické a náboženské zápasy sa výrazne premietli do vývinu školstva, pričom pedagogické ciele protestantského a katolíckeho školstva sa v podstate nelíšili.(Čaplovič, D., 2000. s. 155)

Uhorské zákonodarstvo sa do roku 1681 priamo nedotýkalo protestantského školstva. Snemy v rokoch 1608 a 1647 zabezpečovali protestantom v Uhorsku náboženskú slobodu, ale rozpory sa rozrastali medzi panovníkmi a stavmi, medzi katolíkmi a protestantmi a vyvrcholili v ozbrojené povstanie. Postupujúca rekatolizácia ${ }^{*}$ priniesla číselný úpadok evanjelického školstva, ale najcitlivejšie sa ho dotkli opatrenia po wesselényionskom sprisahaní (1671). V týchto časoch nebol známy pojem tolerancia. Mnohí kazatelia a učitelia museli opustit svoje miesta a evanjelické školy prechádzali do rúk katolíkov, alebo zanikali. (Mátej, J. a kol., 1976. s. 151)

Koncom 16. storočia bolo v Uhorsku len 173 škôl, a to 127 latinských a 46 dedinských. Z toho na Slovensku bolo 78 latinských a 29 dedinských, čo bolo menej ako polovica stavu pred vpádom Turkov do Uhorska. Negramotný luud však nežil

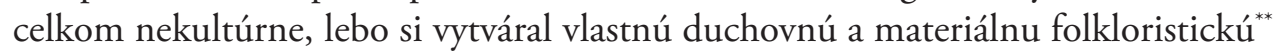
kultúru. (Srogoň, T., 1981. s. 138)

$\mathrm{Na}$ šopronskom sneme $\mathrm{v}$ roku 1651, zák. článkom XXV a XXVI obnovuje sa náboženská sloboda podla viedenského mieru a povoluje sa návrat kazatelom a učitelom do vlasti a sloboda vierovyznania. Po týchto ustanoveniach znovu ožili viaceré evanjelické školy, alebo sa udržiavali tajne. Aj evanjelickí páni zriad’ovali na svojich kúriách nižšie a gramatické školy pre svojich synkov, na ktoré priberali aj chudobnejších chlapcov a vydržiavali ich. Takýchto škôl vzniklo na Slovensku niekol'ko, miesta na ktorých si mohli stavat protestanti kostoly a školy, nazývajú sa artikulárnymi, t. j. podla zák. článkov čiže artikul a podl'a tohto sa udomácnil aj názov artikularné školy.(Mátej, J. a kol., 1976. s. 151)

\footnotetext{
* opätovné obrátenie na katolícku vieru, pokatoličtenie;

** folklórny, národopisný ráz, resp. snaha uplatňovat', zdôrazňovat folklór;
} 
Politická a náboženská situácia v prvej polovici 18. storočia významne vplývala aj na rozvoj školstva, ktoré si nad’alej udržiavalo konfesionálny ${ }^{*}$ charakter. Dozor nad katolíckymi školami mala komisia zriadená roku 1724 pri Miestodržitel'skej rade a otázky protestantského školstva zostali v kompetencii komisie pre náboženské záležitosti. Z vyše 20 katolíckych gymnázií na Slovensku bolo začiatkom 18 . storočia $14 \mathrm{v}$ rukách jezuitov. Ostatné gymnázia - v Podolinci, Prievidzi, Nitre, Brezne, Krupine a v Jure pri Bratislave spravovali piaristi* ${ }^{* *}$. Jedinými strednými školami, ktoré nespravovala cirkev, ale štát, boli v tomto čase banícka škola v Banskej Štiavnici, založená roku 1735 a v Smolníku, založená roku 1746. Protestantské školstvo bolo najviac postihnuté diskrimináciou v čase, ked’ sa v ňom začali uplatňovat́ moderné pedagogické metódy. V zmysle Resolutio Carolina ${ }^{* * *}$ mohli mat́ protestanti na Slovensku, okrem niekol'kých výnimiek, iba nižšie gymnáziá bez humanitných tried. V dôsledku nariadenia zanikli humanitné triedy na lýceách v Banskej Štiavnici, Kremnici, Košiciach, Banskej Bystrici a inde. Roku 1766 bolo v celom Uhorsku 35 evanjelických gramatických škôl, z ktorých väčšina bola na území Slovenska. (Čaplovič, I. a kol., 2000. s. 168)

\section{Ratio educationis}

„Ak je blaho štátu tým prvoradým cielom, na ktorý sa majú zameriavat všetci občania, potom práve toto blaho musi byt základom, na ktorom má stát celá budova vlastnej výchovy. "(Ratio educationis $1777 \& 1806,1988$. s. 9)

Snahy o školské reformy v Rakúsku a Uhorsku sa prejavili už v sedemdesiatych rokoch 18. storočia. Mária Terézia (1740-1780) pokladala školskú reformu v rámci centralizácie za politický čin a školstvo chápala ako politikum. Po dôkladnej úvahe poverila Jána Ignáca Felbigera (1724-1788), aby vypracoval návrh na školskú reformu v Rakúsku. Felbiger na základe výskumu dvornej študijnej komisie a vlastnej skúsenosti vypracoval návrh novej úpravy vyučovania, ktorý Mária Terézia r. 1774

\footnotetext{
* náboženský;

** člen rehol'ného mužského rádu zameraného na pedagogickú činnost;;

*** nariadenie o úprave náboženských pomerov v Uhorsku. Vydal ho 21. marca 1731 král' Karol III. Vychádzalo zo zákonov z r. 1681 a 1687 a ako štátne náboženstvo potvrdilo rímskokatolícke náboženstvo. Protestanti mohli svoje náboženstvo slobodne vyznávat iba na artikulárnych (vyhradených) miestach, volit si superintendentov, ktorí ordinovali kňazov, a vydávat nariadenia vo vieroučných a morálnych otázkach. Pri krste podliehali dozoru katolíckych duchovných. Nariadenie Resolutio Carolina zrušil tolerančný patent (1781). (Bartl, J. a kol,, 1997. s. 287)
} 
prijala a vyhlásila za V̌seobecný školský poriadok pre nemecké normálne, hlavné a triviálne školy v spojených cisársko-královských dedičných krajinách (Allgemeine Schulordnung für die deutschen Normal-Haupt und Trivialschulen in sämtlichen Kaiser., Königl. Erbländern). Tento návrh bol základom historickej reformy sústavy národného školstva v Rakúsku. Jej organizačným a didaktickým sprievodcom bol aj Felbigerov spis Kniha metód pre učitelov nemeckých škôl v cisársko-královských dedičných krajinách... (Methodenbuch für die Lehrer der deutschen Schulen in den kaiserlich-königlichen Erbländern... 1775). (Ratio educationis 1777\&1806, 1988. s. 11)

Školstvo bolo dlhé obdobie v rukách jezuitov. V roku 1773 však pápež Kliment XIV. Jezuitský rád zrušil a v roku 1788 bola v monarchii zavedená povinná školská dochádzka od 6 do 12 rokov. (Ružbárska, M., 11/2003. s. 17)

Zrušenie jezuitského rádu znamenalo vznik novej situácie v oblasti školstva. Do rúk štátu sa na jednej strane dostali majetky rádu, i ked’ v konečnom dôsledku nestačili na plné zabezpečenie učitel'ských síl a potrieb jednotlivých škôl, na druhej strane sa mohlo viac pozornosti venovat́ obsahovej prestavbe celého systému vzdelávania. $\mathrm{V}$ jeho rámci sa pomerne jednoznačne kládol dôraz na rozvoj ludového školstva a na presadzovanie idey jednotnej štátnej vzdelanosti širokých vrstiev obyvatel'stva. (Kowalská, E., 1987. s. 16)

Do rámca osvietenských reforiem, ktoré mali prispiet k zvýšeniu vzdelania l’udu ako základného bohatstva štátu patrilo aj úsilie o reorganizáciu systému vzdelávania. Panovníčka poverila osobitnú komisiu úlohou vypracovat nový študijný poriadok pre katolícke školstvo v Uhorsku.(Bartl, J. a kol., 1997. s. 282)

Mária Terézia schválila 2. augusta 1777 návrh vypracovaný dvornou študijnou komisiou pod vedením Jozefa Ürményiho a vydala pod názvom Ratio educationis. Jeho spoluautorom bol Daniel Terstanský a neoficiálne aj Adam František Kollár. Touto reformou sa v Uhorsku utvorila relatívne jednotná školská sústava, lebo sa dotýkala všetkých stupňov škôl i ked’ nie úplne a definitívne. Neúplné a nedôsledné boli smernice o ludových školách, ktoré sa roku 1778 doplnili v Budíne v dokumente Projectum Budensae, ktorý nebol schválený. O dva roky vyšla „Krátka inštrukcia“, v ktorej bol schválený rozvrh hodín pre ludové školy a učitel'ské kurzy a zoznam predmetov. Triviálne, hlavné a normálne školy sa podla Ratia zorganizovali podobne ako v Rakúsku podla Felbigerovho Schulordnungu. (Srogoň, T. a kol., 1981. s. 141-142)

Systém obsahoval študijný a disciplinárny poriadok, normy pre telesnú, rozumovú a mravnú výchovu. Cielom výchovy bol občan, prakticky vzdelaný, primerane svojmu spoločenskému postaveniu. (Bartl, J. a kol., 1997. s. 282)

Ratio educationis sa sústred’ovalo iba na reformu katolíckeho školstva, ale vyslovila sa požiadavka, aby sa podl'a novej sústavy upravilo aj protestantské školstvo. Na katolícke školy mohli mat́ prístup aj nekatolíci. Finančná starostlivost́ o školy sa preniesla na obce, ktoré platili učitel'ov a udržiavali budovy. Na vývoji vyučovania 
a na reformách školstva sa významne podielali aj mnohí slovenskí pedagógovia. Matej Bel (1684-1749) počas pôsobenia na evanjelickom lýceu v Bratislave uplatňoval pietistické výchovné názory. Juraj Fábri (1718-1779) pôsobil na školách v Prešove a Kežmarku. Už pred reformami Márie Terézie načrtol pokus školskej reformy. Významný predstavitel' osvietenskej pedagogiky bol Samuel Tešedík (1742-1820), ktorý sa svojou pedagogickou činnostou, ludovou osvetou a vzdelávaním mládeže pokúsil svojpomocne riešit kultúrnu, spoločenskú a ekonomickú zaostalost́ dedinského l’udu. (Čaplovič, I. a kol., 2000. s. 170)

Ratio educationis školy delí na národné (ludové), latinské a univerzity.

Národné školy sa zadelujú do štyroch typov podla zamestnania a osídlenia obyvatelov.

Latinské školy sa delili na gramatické (I. - III. trieda), humanoria* (I. - II. trieda) a na královské akadémie s dvojročným filozofickým a dvojročným právnickým kurzom.

Štúdium na univerzite sa v Ratio educationis podrobnejšie nerozvádza, lebo jeho reforma sa už uskutočnila, ale perspektívne sa mali zriadit nové katedry, najmä technického smeru a univerzita dostala novú úlohu, usmerňovat štúdium, organizovat školy v Uhorsku a rozvíjat vedecké bádanie. (Mátej, J. a kol., 1976. s. 209-210)

Tri typy l'udových škôl poskytovali základné vzdelanie, štvrtý typ slúžil na vzdelávanie učitelov ludových škôl. Latinské školy mali tri stupne. Prvým boli gramatické triedy, druhým dve humanitné triedy, ktoré spolu s gramatickými tvorili gymnázium. Tretím stupňom boli akadémie, v ktorých mala dokončit štúdium šlachtická mládež. Štát mal nad školami vrchný dozor. Udržiavat budovy škôl a platit učitelov mali samotné obce. (Bartl, J. a kol., 1997. s. 282).

\section{Ludové školy}

Ludové školy sa delia podlla množstva vyučovacích predmetov, ktoré určuje zamestnanie a osídlenie obyvatel'ov a podl'a počtu učitelov na štyri typy:

1. Ludové školy na dedinách pre potreby rol'níkov s jedných učitelom.

2. Ludové školy v mestečkách pre potreby remeselníkov s dvoma učitel'mi.

3. Ludové školy $\mathrm{v}$ mestách pre remeselníkov a obchodníkov s troma učitel'mi.

4. Ludové školy vzorné alebo normálky $\mathrm{v}$ sídlach dištriktov, na ktorých sa vzdelávali aj učitelia l’udových škôl. Na týchto školách boli tie isté vyučovacie predmety ako na školách v meste. Kandidáti učitel'stva sa tu cvičili vo vyučovacej metóde, v krasopise, v kreslení, učili sa geometriu, základy fyziky a hudby. (Mátej, J. a kol., 1976. s. 169)

* školy s humanitným zameraním; 


\section{Latinské školy}

Ratio educationis rozdeluje latinské školy do troch stupňov:

1. Gramatické školy (I. - III. triedy). Tu sa mala mládež pripravovat na dalšie vzdelávanie sa alebo aj na životné povolanie, na remeslo, obchod, polnohospodárstvo, za nižších úradníkov, na vojenskú dráhu. Podla týchto úloh bolo vymedzené aj učivo. Prevládalo však vyučovanie latinského jazyka a nebolo to odborné vzdelávanie, ale skôr len súhrn základov všeobecného vzdelania, v ktorom sa dostalo miesto i reáliám.

2. Druhým stupňom boli dve humanitné triedy, ktoré s gramatickými triedami tvorili gymnázium. Na týchto sa rozširovalo všeobecné vzdelanie a mladíci sa pripravovali bud' na vyššie školy, alebo do praktického života, za kňazov, učitel'ov gramatických škôl, za tajomníkov magnátov, knihovníkov alebo správcov rodinných majetkov. Gymnáziá v dištriktuálnych* miestach sa volali archigymnáziá. Boli to vlastne vzorné školy a v sídlach akadémií mali spoločného riaditel’a $s$ akadémiou. Na Slovensku sa archigymnáziá mali zriadit́ v Bratislave, Banskej Bystrici a v Trnave.

3. Tretí stupeň latinskej školy tvorili akadémie, na ktorých sa gymnaziálne štúdiá dopíňali dvojročným kurzom filozofie a dvojročným kurzom práva. Podl'a Ratio educationis úlohou akadémií bolo poskytovat dokonalejšie vzdelanie a šlachtickí mladíci si na nich mali dokončievat svoje štúdiá. Na filozofickom kurze sa predmety gymnázia rozširovali a aplikovali na hospodársky život. Ako nové predmety sa vyučovali filozofia a pol'nohospodárstvo a v rámci matematiky sa prednášali aj partie z geodézie, hydrotechniky a z civilného stavitel'stva, ale s praktickým zameraním na ich využitie najmä v pol'nohospodárstve. (Mátej, J. a kol., 1976. s. 169)

\section{O štúdiu na lýceách a akadémiách všeobecne}

Obidvom týmto typom škôl sú určené tie druhy štúdia, ktoré vedú k rôznym ciel'om určeným mládeži: aby sa ich žiaci posilnili aj pre d’alší život hlbším poznaním krestanského náboženstva, vierouky s dogmami a prikázaniami katolíckej cirkvi, v cvičeniach zbožnosti, v správaní a návykoch; aby sa vzdelávali vo filozofických a matematických disciplínach, $v$ poznávaní prírodných tajomstiev, síl a zákonov a v skutočnom umení múdrosti; aby nadobudli vynikajúce vedomosti nielen o vlasti a pripojených provinciách a o vnútornom politickom zriadení, ale aby obsiahli

* územná správna jednotka (v niektorých krajinách); u nás v minulosti okrsok, obvod; 
aj celé dejiny; aby dôkladne preskúmali domáce a verejné zákony, aby dokonale poznali stav vecí týkajúcich sa náboženstva, vojenstva, občianskeho a štátneho hospodárstva, ako aj pol'nohospodárstva, remesiel a obchodu; d’alej nech sú im jasné právne vztahy týkajúce sa zmlúv, dohôd, spojení a mierových zmlúv so susednými štátmi, pretože $\mathrm{v}$ týchto prameňoch sa má preskúmat', ako sa možno právnicky dohodnút so susednými krajinami, ako sa dá pozdvihnút blaho krajiny a ako to možno docielit. (Ratio educationis $1777 \& 1806$, 1988. s. 309)

Toto všetko jasne poukazuje na nevyhnutnost́ rozdelit celé toto štúdium na dve časti. Prvá z nich sa bude venovat filozofii a s ňou súvisiacim disciplínam; druhá čast' právu a verejnej správe. K tomu sa pridá gréčtina a domáci jazyk; gréčtina pre poslucháčov filozofie, ktorí pomýšlajú na teológiu a medicínu, domáci jazyk pre týchto a všetkých poslucháčov akadémie, ktorí sa chcú v budúcnosti venovat verejným královským úradom.

Mad’arský jazyk bude ovládat vo vyšších triedach škôl* už každý z domácich poslucháčov, ak sa dokonale zachováva všetko, čo sa na gramatických a humanitných školách starostlivo uzákonilo. Keby sa však predsa našli takí, pre ktorých mad’arčina nie je materinským alebo dost́ známym jazykom, budú sa cvičit v gramatike, zatial' čo ostatní sa budú cvičit v zdokonalovaní tohto jazyka, v čítaní diel vynikajúcich autorov na tých hodinách, na ktorých sa môžu zúčastnit poslucháči filozofie aj práva bez vymeškania ostatných prednášok. (Ratio educationis $1777 \& 1806,1988$. s. 310)

\section{O študijnom poriadku vo filozofickom kurze}

Vzdelávanie tohto druhu sa nebude zaoberat iba tým, aby ukazovalo ostatným smer a s akousi služobnou úslužnostou poskytovalo nevyhnutné prostriedky, ale aby aj štátu poskytlo zo svojho stredu čo najviac užitočných občanov. To všetko sa jasne ukáže z absolvovania sem patriacich disciplín, ktoré sú zahrnuté do dvojročného kurzu.

(Ratio educationis $1777 \& 1806,1988$. s. 310)

$\mathrm{V}$ prvom roku sa preto bude preberat:

a) teoretická filozofia, pričom sa odstránia zbytočné pojmy, rozdelenia a výroky,

b) pragmatické dejiny uhorského královstva s vynechaním úvodu, ktoré zahrňujú pôvod a hlavné zmeny štátneho zriadenia, ich príčiny, a tiež pôvodné pramene, ako ich vyložil vynikajúci autor Pray,

c) taktiež teoretická matematika s geodéziou.

$\mathrm{V}$ druhom roku sa bude preberat:

* výraz vyššie triedy v Ratiu educationis z r. 1806 znamená akadémiu a univerzitu 
a) teoretická a experimentálna fyzika,

b)' bude sa pokračovat'v teoretickej filozofii, ktorú uzavrie praktická filozofia,

c) pridá sa aplikovaná matematika,

d)' v̌̌eobecné dejiny,

e) polnohospodárstvo so stručným výkladom prírodopisu.

(Ratio educationis 1777\&1806, 1988. s. 311)

Tento filozofický kurz bude musiet absolvovat každý, kto sa chystá študovat medicínu, právo alebo teológiu a chce dosiahnut verejné vysvedčenie.

Pretože gréctina je rozšírená vo všetkých disciplínach a je najviac užitočná a potrebná pre tých, ktorí by sa po ukončení dvojročného štúdia filozofie radi venovali krásnym umeniam, medicíne alebo teológie, bude tu jej štúdium volitel'né a bude mat svojho vlastného profesora, ktorý by ju prednášal na hodinách mimo riadneho vyučovacieho času študentom zaujímajúcim sa o grécku kultúru a pripravoval by ich do vyšších tried.

(Ratio educationis $1777 \& 1806,1988$. s. 312) (pozri prílohu tabul'ka 8.)

\section{O študijnom poriadku v právnickom kurze}

Kedže akademický kurz sa končí právnickými štúdiami, odkial' mládež odchádza bud' zastávat verejné úrady, žit súkromným životom, alebo napokon d’alej na univerzitu kvôli získaniu vyššieho vzdelania, je zrejmé, že tu počas štúdia treba poskytnút viac možností zaoberat’ sa rôznymi dôležitými disciplínami. Na ich preberanie sa ustanovuje nasledujúci poriadok.

V prvom roku

a) jeden profesor vysvetluje prirodzené právo, taktiež všeobecné verejné a medzinárodné právo a v spojitosti s nimi aj uhorské verejné právo,

b) druhý profesor zas vysvetl'uje verejné a súkromné cirkevné právo. V druhom roku práve tol'ko profesorov bude prednášat

a) rímske občianske právo, potom stručne vysvetlia feudálne právo a napokon trestné právo,

b) verejnosprávne a obchodné poznatky spolu s peñažníctvom všeobecne nazývaným kamerálnou* vedou, ako aj bankové a obchodné právo. Zásady verejnoprávnych vied, obchodu a peňažníctva sú všeobecné a spoločné pre všetky vzdelané národy, avšak ich použitie a praktické uplatnenie vzhl'adom na rôzne osobitosti, zákony a prijaté zvyky národov nemôžu byt všade tie isté. Preto tu profesor bude brat vždy ohl'ad na domáce zákony a pomery.

\footnotetext{
* prislúchajúca alebo slúžiaca královskej komore;
} 
Aj v tretom roku sú dvaja profesori

a) prvý prednáša a vysvetluje uhorské súkromné čiže domáce právo a učí štýl právnických spisov,

b) povinnostou druhého profesora je vysvetlovat' v prvom polroku - štatistikuUhorska a iných panstiev prislúchajúcich cisársko-královskému dvoru, ako aj iných európskych královstiev, $\mathrm{v}$ druhom polroku - banské právo.

Ratio educationis obsahuje okrem organizácie školstva študijný a disciplinárny poriadok, normy pre telesnú, rozumovú a mravnú výchovu a administratívne predpisy. Ratio educationis je na svoju dobu vynikajúce dielo. Nadväzuje na pokrokové tendencie, uplatňujú sa v ňom už vtedajšie vládnuce pedagogické zásady, má interkonfesionálne znaky a mimoriadnu pozornost́ venuje telesnej výchove. Celé dielo je triedne zamerané, člení jednotlivé stupne a typy škôl podl’a vtedajšej spoločenskej štruktúry. Dielo nevymedzovalo školopovinnost́. Žiada, aby deti navštevovali školu, pokial' nebudú schopné vykonávat pol'nohospodárske práce. Neurčilo vekovú hranicu zaškolovania detí. Vyslovuje sa $\mathrm{v}$ ňom len zásada, že žiak zadostučiní školskej povinnosti, ked' ovláda učivo predpísané pre dedinské školy. Iba Jozef II. prvý uzákonil (1788) obdobie školopovinnosti od 6. do 12. rokov a vytýčil aj sankcie. (Mátej, J. a kol., 1976. s. 166)

Aj ked' Ratio prihliadalo na vtedajšie požiadavky, nevyriešilo dôsledne mnohé otázky. Napríklad kým náklady na latinské školy, normálky a univerzitu sa mali uhrádzat zo študijného fondu, o triviálne školy sa mali starat obce, poddaný lud. (Srogoň, T. a kol., 1981. s. 142)

UUroveň školstva v 18. storočí mala významný vplyv aj na úroveň vzdelanosti. Nerovnomerné rozloženie dedinských škôl a zlé podmienky učitel'ov mali za následok, že vel'ká čast poddanského obyvatel'stva bola negramotná alebo len sčasti ovládala základy čítania, písania a počítania. Lepšia situácia bola $\mathrm{v}$ mestách, kde sa venovala školám väčšia pozornost'. Takmer všetci obyvatelia významnejších slobodných královských miest mali základné vzdelanie a ovládali aj viacero jazykov. O vysokom stupni vzdelanosti vo väčších mestách svedčila skutočnost́, že takmer v každej domácnosti sa nachádzali knižné diela. V tomto období vznikali základy mnohých inštitucionálnych knižníc. Dôležitú úlohu v oblasti osvety zohrávalo vydávanie novín a kalendárov. (Čaplovič, I. a kol., 2000. s. 170)

Od devätdesiatych rokov 18. storočia charakteristickým znakom školskej politiky v Uhorsku je zápas o kompetenciu v otázkach výchovy a školstva medzi snemom a panovníkom a úsilie zaviest́ mad’arčinu do škôl a úradov. Na sneme r. 1790-1791 sa stavy usilovali zabezpečit konfesionálnu slobodu, vplyv na riešenie otázok výchovy a školstva a zákaz cudzej reči do úradovania. Štátna rada miernila mad’arizačné

\footnotetext{
* týkajúco sa vzájomných vztahov medzi konfesiami, konfesijne nestranný;
} 
snahy a mad’arčina (1792) sa uzákonila iba ako riadny predmet na latinských školách. (Mátej, J. a kol., 1976. s. 212)

V školskej politike Jozef II. (1780-1790) bol dôslednejší a pokrokovejší, v iných zas spiatočnícky a unáhlený. Pokrokovým činom bolo, že v Inštrukcii pre vizitáto$\operatorname{rov}^{*} \Sigma^{5} k \hat{l} l$ určil jednoznačne školopovinnost' detí od 6. - 12. roku, nariadil každoročný súpis detí, vyučovanie vyhlásil za bezplatné a absencie žiakov trestal. V každej obci, kde bola fara, mala sa zriadit aj škola, do ktorej museli chodit aj deti zo susedných obcí, vzdialených menej ako pät kilometrov a mohli ju navštevovat́ aj deti iných vierovyznaní, ak nemali vlastnú školu. Podstatné zmeny urobil aj v oblasti vyšších škôl. Študijný fond poštátnil, správu sedmohradských škôl podriadil tiež viedenskej študijnej komisii, školský dozor a školské poriadky postavil na neobmedzených slobodných princípoch. Zrušil povinné bohoslužby a účast študentov na náboženských úkonoch, povolil im návštevu divadiel i zábavných lokálov. Zrušil aj konvikty* $^{* *}$ a d’alšie rehole aj s ich školami okrem piaristov, alebo dosadil na ne protestantských profesorov, čím vyvolal vlnu nespokojnosti. Spiatočníckym rozhodnutím bolo zavedenie poplatkov, i to, že na stredné školy pripustil študovat len deti zámožných rodičov. Nemčinu zaviedol ako povinný predmet na všetkých stredných školách a na viacerých aj ako vyučovací jazyk. Zásahy Jozefa II. do školských otázok boli jednostranné, prevažne len politické, menej pedagogické. Všeobecná nespokojnost's jeho politikou ho na sklonku života doviedla k rozhodnutiu odvolat takmer všetky nariadenia aj v oblasti školskej politiky.(Srogoň, T. a kol., 1981. s. 142)V prepracovanom školskom systéme zo 4. novembra 1806 (tzv. druhé Ratio educationis) vznikli gymnáziá s vyšším kurzom filozofie, nazývané lýceá, právnické štúdium na akadémiách trvalo 3 roky, gymnázium malo šest́ tried. Protestantské školstvo sa aj nad’alej riadilo vlastným poriadkom.(Bartl, J. a kol., 1997. s. 283)

\section{Záver}

Nové vydanie Ratio educationis z roku 1806 naznačilo potrebu venovat pozornost́ predmetom, ktoré by dávali žiakom praktické znalosti z oblasti „technológie“, hospodárskeho zemepisu a základov hospodárskej náuky, pôsobenie tried s týmto vyučovacím programom sa však nepodarilo v dostatočnej miere zabezpečit. Hoci ludové školy boli zamerané na to, aby poskytli detom podla ich sociálneho pôvodu ucelené vzdelanie, stali sa zároveň základnými, pretože absolvovanie troch tried

\footnotetext{
* ten kto robí vizitáciu (pravidelná prehliadka duchovnej správy (predtým aj školy) konaná biskupom alebo vikárom);

** historický ústav zriad’ovaný pri kláštoroch a poskytujúci študentom byt, stravu a výchovný dozor, katolícky internát, ubytovňa; resp. kláštorná budova;
} 
hlavnej alebo normálnej školy a zvládnutie základov latinčiny (časovania a skloňovania) bolo podmienkou pre prijatie na štúdium na strednej škole. Preto sa latinčina dostala do učebného plánu, aj ked' ako nepovinný predmet. Úrovni vyučovania latinčiny sa venovala pomerne vel'ká pozornost a aj počas prípravy nového vydania Ratio educationis sa zdôrazňovalo, že hlavné a normálne školy nedosiahli očakávané výsledky v príprave žiakov na štúdium na latinských - stredných školách. Presadenie pričlenenia troch tried ku gymnáziám, kde sa latinčina vyučovala podla nového učebného plánu, bolo motivované aj úsilím zvýšit úroveň vyučovania latinčiny a dokumentuje význam, ktorý latinčina začiatkom 19. storočia ešte mala vo verejnom živote. (Kowalská, E., 1987. s. 57-58)

Ratio educationis bolo záväzné len pre katolícke školy. Na sneme r. 1844 sa uzákonila mad’arčina ako vyučovací jazyk. V tomto období vyšlo tlačou viacero súkromných návrhov na úpravu školstva alebo kritík vtedajšieho školstva v Uhorsku. Posledná úprava jednotného študijného poriadku spadá do obdobia, ked' začalo vrcholit úsilie o pomad’arčenie evanjelických škôl. Požiadavka, aby sa zaviedla mad'arčina ako vyučovací jazyk, neostala bez ohlasu u slovenských evanjelikov. Zazlievalo sa návrhu, že nezahrnul vyučovanie slovenského jazyka a literatúry do vy̌̌ších škôl. Jednotný systém a študijný plán pre evanjelické školy bol publikovaný v roku 1842. (Mátej, J. a kol., 1976. s. 212)

Uvedené fenomény a skutočnosti mali dopad na sociálnu prácu, uvádzam niektoré prieniky.

\section{Bibliografia}

BARTL, J. a kol., (1997): Lexikón slovenských dejín. Bratislava: SPN, 1. vydanie. 1997.

ČAPLOVIČ, D. a kol., (2000): Dejiny Slovenska. Bratislava: AEP -Academic Electronic Press,

KATUŠČÁK, D., (2007): Ako pisat' záverečné a kvalifikačné práce. Nitra: Enigma, 164

KOVÁČ, D. a kol., (1998) Kronika Slovenska I. - Od najstaršich čias do konca 19. storočia. Bratislava: Fortuna Print \& Adox,

KOWALSKÁ, E, (1987): Štátne lúdové školstvo na Slovensku na prelome 18 a 19. storočia. VEDA, Bratislava: Slovenská akadémia vied,

KOWALSKÁ, E, (1990): Školstvo a vzdelanost́ na Slovensku 1740-1780,Vlastivedný časopis,

KOWALSKÂ, E., (2006): Ked’ škola prestala byt predsieňou kostola. História,,2/2006 ročník V., č. 2, 
MÁTEJ, J. a kol., (1976), Dejiny českej a slovenskej pedagogiky. Bratislava: Slovenské pedagogické nakladatel'stvo,

Ratio educationis 1777 a 1806. (1988). Prvá jednotná sústava výchovy a vzdelávania v dejinách našej kultúry (preklad Mikleš, J. a Novacká $M$ ). Bratislava: Slovenské pedagogické nakladatel'stvo

RUŽBÁRSKA, M.,: (2003) Mária Terézia panovníčka reforiem. Historická revue,, 11/2003roč. XIV., č. 11

SROGOŇ, T. a kol., (1981) Dejiny školstva a pedagogiky. Bratislava: Slovenské pedagogické nakladatel'stvo

VANĚKOVÁ, D., (1997), Elementárne školstvo od Márie Terézie po koniec I. ČSR. /Výstava, Levoča, 29.4. - 29. 6. 1974/ Múzeum. ročník XL., č. 3,

\section{History of education in Slovakia with regard to social work}

Resume focused on Slovak history of pedagogy from the earliest days, school framework within the school system Ratio educationis, where we describe in detail folk schools and Latin schools, and studies at academies and lyceums themselves in individual subchapters.

Keywords: History of pedagogy, School and education, Ratio educationis, Folk schools, Latin schools,

\section{Historia edukacji na Słowacji w zakresie pracy socjalnej}

\section{Streszczenie:}

Artykuł koncentruje się na słowackiej historii pedagogiki, charakteryzuje system Ratio educationis, w ramach którego opisane zostają szkoły ludowe i szkoły łacińskie.

Słowa kluczowe: historia pedagogiki, szkoła i edukacja, ratio educationis, szkoły ludowe, szkoły łacińskie 